PATIK : Jurnal Hukum

https://ejournal.uhn.ac.id/index.php/patik

Volume 09 Nomor 01 April 2020 Page : 60 - 69

p-issn : 2086 - 4434

\title{
PERTANGGUNGJAWABAN PIDANA PELAKU PENYEBAR HOAX YANG DAPAT MENJATUHKAN WIBAWA KEPALA NEGARA (STUDI PUTUSAN NO : 196/Pid.Sus/2019/PN BKS)
}

\author{
Andreas Parulian, Herlina Manullang, Kasman Siburian \\ Fakultas Hukum, Universitas HKBP Nommensen \\ herlinamanullang@uhn.ac.id
}

\begin{abstract}
Abstrak
Masalah pencemaran nama baik dan penyebaran berita bohong atau hoax akhirakhir ini saat merebak di masyarakat. Permasalahan dalam penulisan ini mengarah pada Pertanggungjawaban Pidana Pelaku Penyebar Hoax Yang Dapat Menjatuhkan Wibawa Kepala Negara dalam putusan Nomor: 196/Pid.Sus/2019/PN Bks. Penelitian ini bersifat normatif menggunakan sumber bahan hukum primer dan bahan hukum sekunder. Dengan pendekatan masalah berupa pendekatan perundang-undangan dan pendekatan kasus. Berdasarkan hasil penelitian dan pembahasan yang dilakukan oleh penulis dalam Putusan Nomor : 196/Pid.Sus/2019/PN Bks untuk menentukan bahwa seseorang memiliki aspek pertanggungjawaban pidana maka dalam hal itu terdapat beberapa unsur yang harus terpenuhi untuk menyatakan bahwa seseorang tersebut dapat dimintakan pertanggungjawaban yaitu unsur adanya suatu tindak pidana, kemampuan bertanggungjawab, kesengajaan, tidak ada alasan pemaaf. Dalam kasus yang diteliti penulis, Majelis Hakim tidak menemukan hal-hal yang dapat menghapuskan pertanggungjawaban pidana sebagai alasan pemaaf, maka terdakwa harus mempertanggungjawabkan perbuatannya dan karena terdakwa mampu bertanggungajawab maka terdakwa harus dinyatakan bersalah dan dijatuhi pidana.
\end{abstract}

\section{Kata Kunci: Pertanggungjawaban Pidana Pelaku Penyebar Hoax, Kepala Negara}

\begin{abstract}
The problem of defamation and the spread of fake news or hoaxes has recently spread in society. The problem in this writing leads to the Criminal Accountability of Hoax Spreaders Who Can Impose the Authority of the Head of State in decision Number: $196 /$ Pid.Sus / 2019 / PN Bks. This research is normative in nature using primary legal materials and secondary legal materials. With a problem approach in the form of a statutory approach and a case approach. Based on the results of research and discussion carried out by the author in Decision Number: 196 / Pid.Sus / 2019 / PN Bks to determine that a person has aspects of criminal responsibility, in that case there are several elements that must be fulfilled to state that a person can be held accountable, namely elements of a criminal act, the ability to be responsible, deliberate, there is no excuse for forgiveness. In the case that the author investigated, the Panel of Judges did not find anything that could eliminate criminal responsibility as an excuse for forgiveness, the defendant had to be accountable for his actions and because the defendant was able to be responsible, the defendant had to be found guilty and sentenced to crime.
\end{abstract}

Keywords: Criminal Accountability of Hoax Spreaders, Head of State 
PATIK : JURNAL HUKUM Vol : 09 No. 1, April 2020, Hal 60 - 69

\section{Pendahuluan}

Pada era digital saat ini, banyak kita temui berbagai macam sumber berita, baik berita yang menyajikan informasi yang benar dan valid seperti pada tayangan Televisi dan surat kabar lainnya yang telah terverifikasi, dan berita yang menyajikan berita kabar bohong atau Hoax, seperti pada akun Facebok atau media sosial lainnya, yang sering disalah gunakan oleh seseorang atau kelompok tertentu untuk memberikan informasi Hoax atau informasi tidak valid kepada masyarakat, untuk menjatuhkan martabat seseorang/pejabat tertetentu, yang dapat menimbulkan presepsi buruk dan provokasi dikalangan masyarat maupun pada pejabat/pemerintah, sehingga menimbulkan kegaduhan. Kabar bohong atau Hoax adalah suatu berita yang tidak benar tentang fakta dan keabsahannya, berita bohong, ialah fakta yang diplintirkan atau direkayasa untuk tujuan politik dan kepentingan kelompok tertentu untuk membuat kegaduhan dan kecemasan bagi masyarakat luas.

Pemanfaatan media sosial di Indonesia saat ini berkembang luar biasa bahkan Indonesia menempati urutan ke 6 dunia dalam penggunaan internet (media sosial) ${ }^{1}$. Dengan penggunaan media sosial yang sangat luas tersebut, maka kejahatan terhadap pelanggaran UU ITE rentan terjadi yang dilakukan oleh kelompok tertentu untuk menyerang kolompok lainnya yang dipenuhi berita informasi palsu Hoax, provokasi, fitnah, sikap intoleran, dan anti Pancasila.

Kemajuan teknologi di era globalisasi membuat informasi begitu cepat beredar luas. Keberadaan internet sebagai media online membuat informasi yang belum terverifikasi benar, langsung beredar luas dimasyarakat. Hanya dalam hitungan detik, suatu peristiwa sudah bisa langsung tersebar dan diakses oleh pengguna internet melalui media sosial. Bahkan masyarakat pada umumnya belum memahami materi informasi yang disebarkan, namun reaksi atas informasi tersebut sudah lebih dahulu dinilai dengan respon beragam Mulai respon Positif seperti menyaring dan mencari kepastian informasi berita yang disebarkan, hingga respon negatif yang mendukung dan menyebarkan informasi tersebut tanpa mengoreksi kebenaranya sehingga menyebabkan seseorang dapat dipersalahkan karena melanggar ketentuan UU ITE.

Dalam KUHP terdapat delik penghinaan tentang Kejahatan terhadap Martabat Presiden dan Wakil Presiden yaitu pasal 134 dan Pasal 137 tentang Penghinaan Kepada Presiden dimuka umum ${ }^{2}$. Jika penghinaan dan atau pencemaran nama baik dipidana berdasarkan Pasal 27 ayat (3) UU ITE. Dan jika bermuatan menimbulkan rasa kebencian berdasarkan SARA dipidana berdasarkan Pasal 27 ayat (2) UU ITE.

Seperti kasus dibawah ini bahwa terdakwa atas nama Ashyadu Amrin terbukti memposting di facebooknya pada tanggal 7 Oktober 2017 dengan judul "Kalau gak ngutang, ya jual asset negara. Itu kehebatan Jokowi". Dan pada tanggal 20 November 2017 terdakwa juga memposting pada akun facebook nya dengan judul "Beda Level, Umar Bin Khattab adalah Khalifah, sementara Jokowi cuma jongosnya aseng dan asing". Postingan terdakwa tersebut dilihat oleh Wisnu Widiatmoko. S.Kom selaku saksi yang juga bekerja sebagai Polisi di Satgas Patroli Siber pada Direktorat Tindak Pidana Siber Bareskrim Polri. Sehingga saksi melaporkan perbuatan terdakwa dan memproses nya. Setelah itu dilakukan penangkapan oleh petugas kepolisian dan menemukan alat bukti berupa Handphone Xiaomi yang digunakan terdakwa untuk menyebarkan postingan Hoax nya di facebook. Setelah polisi melimpahkan kasus tersebut kepada pengadilan, dan Hakim pun menyatakan terdakwa bersalah karena telah menyebarkan berita bohong atau hoax yang bertujuan

\footnotetext{
${ }^{1}$ https://ilmupengetahuanumum.com/10-negara-dengan-pengguna-internet-terbesar-di-dunia/ (diakses tanggal 9 Juni 2020, pukul 14.00)

${ }^{2}$ Andi Hamzah. Delik-Delik Tertentu di dalam KUHP. (Jakarta: Sinar Grafika, 2010), hal. 56
} 
untuk mencemarkan nama baik Kepala Negara atau Presiden. Tersangka pun dijatuhi hukuman penjara selama 2 tahun 6 bulan oleh hakim. Berdasarkan uraian di atas, maka penulis merumuskan suatu rumusan masalah yang akan dibahas dalam penelitian yaitu Bagaimanakah Pertanggungjawaban Pidana Pelaku Penyebar Hoax Yang Dapat Menjatuhkan Wibawa Kepala Negara Dalam Putusan No. 196/Pid.Sus/2019/PN Bks.)

\section{Tinjauan Pustaka}

Konsep liability atau "pertanggungjawaban" dalam hukum pidana merupakan konsep sentral yang dikenal dengan ajaran kesalahan. Dalam bahasa latin ajaran kesalahan dikenal dengan sebutan mens rea. Doktrin mens rea ini dilandaskan pada konsepsi bahwa suatu perbuatan tidak mengakibatkan seseorang bersalah kecuali jika pemikiran orang itu jahat. Didalam doktrin itu, terdapat dua syarat yang harus dipenuhi untuk dapat memidana seseorang, yaitu ada perbuatan lahirlah yang terlarang/tindak pidana (actus reus) da nada sikap batin jahat/tersela (mens rea) ${ }^{3}$.

Pertanggungjawaban pidana di artikan sebagai terusan celaan yang objektif yang ada pada perbuatan pidana dan secara subjektif yang ada memenuhi syarat untuk dapat dipidana karena perbuatannya itu. Dasar adanya perbuatan pidana adalah asas legalitas, sedangkan dasar dapat dipidana pembuat adalah asas kesalahan. Ini berarti bahwa pembuat perbuatan pidana hanya akan dipidana jika ia mempunyai kesalahan dan melakukan perbuatan pidana tersebut. Pertanggungjawaban pidana pada hakikatnya merupakan mekanisme yang dibangun oleh hukum pidana untuk beraksi terhadap pelanggaran atas "kesepakatan menolak" suatu perbuatan tertentu. ${ }^{4}$

Pertanggungjawaban pidana menjurus kepada pemidanaan petindak, jika telah melakukan suatu tindak pidana dan memenuhi unsur-unsurnya yang telah ditentukan dalam Undang-undang. Dilihat dari sudut terjadi suatu tindakan yang terlarang (diharuskan) seseorang akan mempertanggungjawabkan pidananya apabila tindakan tersebut bersifat melawan hukum atau rechtsvaardigingsgrond.

Dilihat dari sudut kemampuan bertanggungjawab, maka hanya yang "mampu bertanggungjawab" yang dapat mempertanggungjawabkan perbuatannya. Jadi, syarat pertanggungjawaban pidana adalah adanya perbuatan, lalu perbuatan tersebut melawan hukum, dilakukan dengan kesalahan (dolus dan culpa). Aspek kesalahan (schuld) merupakan asas fundamental dalam hukum pidana dalam menentukan dapat dipidananya pembuat (culpabilitas) $)^{5}$. Dapatlah dikatakan, bahwa untuk menentukan adanya kemampuan bertanggungjawab ini ada dua faktor, yaitu faktor akal dan faktor kehendak. Akal, yaitu dapat membeda-bedakan antara perbuatan yang diperbolehkan dan yang tidak. Kehendak, yaitu dapat menyesuaikan tingkah lakunya dengan keinsyafan atas mana diperbolehkan dan yang tidak. Memang tidak mudah untuk membedakan antara kesengajaan dengan sadar kepastian dan kesengajaan dengan sadar kemungkinan, karena keduanya berada didalam batin manusia ${ }^{6}$.

Menurut Sudarto pertanggungjawaban pidana adalah dipidananya seseorang tidaklah cukup apabila orang itu telah melakukan perbuatan yang bertentangan dengan hukum atau bersifat melawan hukum. Jadi, meskipun perbuatan tersebut memenuhi rumusan delik dalam undang-undang dan tidak dibenarkan, namun hal tersebut belum memenuhi syarat penjatuhan pidana, yaitu orang yang melakukan perbuatan itu mempunyai kesalahn atau bersalah. Orang tersebut harus dipertanggungjawabkan atas

${ }^{3}$ Mahrus Ali, Asas-Asas Hukum Pidana Korporasi, (Jakarta: Raja Grafindo Persada, 2015), Hal. 93

${ }^{4}$ Mahrus Ali, Dasar-Dasar Hukum Pidana, (Jakarta: Sinar Grafika,2011), Hal.156.

${ }^{5}$ Ishaq. Hukum Pidana. (Jakarta: Rajagrafindo Persada, 2020), hal. 96

${ }^{6}$ Teguh Prasetyo. Hukum Pidana. (Jakarta: Grafindo Perkasa, 2010), hal. 100 


\section{PATIK : JURNAL HUKUM Vol : 09 No. 1, April 2020, Hal 60 - 69}

perbuatannya atau jika dilihat dari sudut perbuatannya, perbuatannya baru dapat dipertanggungjawabkan kepada orang tersebut. ${ }^{7}$

Penghinaan adalah menghina yaitu "Menyerang kehormatan dan nama baik seseorang". Yang diserang itu merasakan malu. Kehormatan yang diserang disini hanya mengenai kehormatan yang dapat dicemarkan ${ }^{8}$. Pengertian Penghinaan dalam KUHP ialah tindak pidana yang menyerang hak seseorang berupa merusak nama baik seseorang atau kehormatan seseorang. Perbuatan ini diatur dalam pasal 315 KUHP yang memuat suatu tindak pidana yang disebut penghinaan bersahaja dan yang dirumuskan sebagai setiap penghinaan dengan sengaja yang tidak bersifat menista ${ }^{9}$.

Istilah Penghinaan yaitu semua jenis kejahatan yang dirumuskan dalam Bab XVI buku II. Dalam pasal 310 ayat (1) dimuat semua unsur, baik yang bersifat objektif (perbuatan/objeknya) maupun yang bersifat subjektif (kesalahan, berupa sengaja melakukan perbuatan dan maksud pembuat dalam hal melakukan perbuatan). Pada kenyataannya memang semua kejahatan yang masuk penghinaan (Bab XVI buku II), maupun penghinaan khusus diluar Bab XVI mengandung sifat yang sama dengan kejahatan pencemaran.

Penghinaan terhadap Presiden dan Wakil Presiden merupakan suatu tindak pidana yang diberi kualifikasi penghinaan khusus yang terdapat di luar Bab XVI yang tersebar pada beberapa pasal yang masuk ke dalam bab yang berbeda-beda objeknya, atau kepentingan hukum yang dilindungi sebagai dasar pengelompokan masing-masing tindak pidana. Oleh karena berbeda-beda dasar pengelompokan penghinaan di luar Bab XVI inilah, maka tidak salah disebut sebagai penghinaan khusus ${ }^{10}$. Mengandung sifat yang sama tidak sama artinya dengan mengandung unsur yang sama. Sifat yang sama, terletak baik pada perbuatannya menyerang, objeknya kehormatan dan nama baik, maupun kesengajaan baik yang ditujukan pada perbuatan maupun yang ditujukan kepada akibat. Dicontohkan kepada pengaduan fitnah, meskipun perbuatannya materilnya (mengajukan pengaduan dan pemberitaan palsu) berbeda dengan perbuatan materil pada pencemaran (menyerang kehormatan dan nama baik) namun sifat kedua kejahatan itu adalah sama. Pencemaran nama baik hanya dapat diproses oleh polisi apabila ada pengaduan dari pihak yang merasa dicemarkan nama baiknya ${ }^{11}$.

Hoax adalah informasi palsu, berita bohong, atau fakta yang diplintir atau direkayasa untuk tujuan lelucon hingga serius (politis). Secara Bahasa Hoax (synonyms: practical, joke, jest, prank, trick) adalah lelucon, cerita bohong, kenakalan, membohongi, menipu, mempermainkan, memperdaya dan memperdayakan. Pengertian Hoax dalam pasal 28 ayat (1) Undang-Undang Nomor 11 tahun 2008 tentang ITE.

Pengertian Media Sosial adalah media digital sebagai tempat terjadinya realitas sosial pada ruang waktu tak terbatas bagi para penggunanya untuk saling berinteraksi. Para ahli mendefinisikan pengertian media sosial dengan struktur bahasa yang berbeda, namun tetap dalam makna dan nilai yang sama. Nilai-nilai yang ada di masyarakat maupun komunitas juga muncul bisa dalam bentuk yang sama atau berbeda di internet. Pada dasarnya, beberapa ahli menggambarkan pengertian media sosial tidak terlepas dari apa

\footnotetext{
${ }^{7}$ Mahrus Ali, Asas-Asas Hukum Pidana Korporasi, Op.cit, Hal 95.

${ }^{8}$ Adami Chazawi. Hukum Pidana Positif Penghinaan. (Malang: Media Nusa Creative,2016), hal.

${ }^{9}$ Ismu Gunadi. Hukum Pidana. (Jakarta: Kencana,2014), hal. 192

${ }^{10}$ Gomgom Siregar. Suatu Analisis Mengenai Tindak Pidana Pencemaran Nama Baik Melalui Media Elektronik. (Bandung: Refika Aditama,2020), hal. 89

${ }^{11}$ Leden Marpaung. Tindak Pidana Terhadap Kehormatan. (Jakarta: Sinar Grafika,2010), hal. 3
} 
yang terjadi saat ini di dunia. Dengan satu konten unik di media, khalayak atau masyarakat dapat tergerak secara masif. ${ }^{12}$

\section{Metode}

Jenis penelitian hukum ini termasuk penelitian yuridis normatif yaitu penelitian yang berdasarkan pada bahan kepustakaan yang ada. Penelitian ini dengan pendekatan studi kasus yang meliputi ketentuan perundang-undangan dan putusan pengadilan serta literatur-literatur yang berhubungan dengan pokok bahasan. Bahan hukum yang dilakukan dalam penulisan penelitian ini adalah dengan cara kualitatif, yaitu analisis terhadap isi putusan Pengadilan Negeri Bekasi No.196/Pid.Sus/2019/PN Bks. Tentang dasar pertimbangan hakim menjatuhkan pidana kepada pelaku yang menyebarkan berita bohong atau Hoax, kemudian dilakukan pembahasan dan penafsiran yang ada pada akhirnya dapat ditarik kesimpulan tentang penjatuhan hukuman oleh hakim itu tepat terhadap terdakwa

\section{Pembahasan Dan Hasil}

Dakwaan adalah tuntutan perkara yang diberikan oleh jaksa penuntut umum dalam bentuk surat dakwaan. Pasal 143 KUHAP menyatakan secara jelas bahwa untuk mengadili suatu perkara, Penuntut Umum wajib mengajukan permintaan disertai dengan suatu surat dakwaan. Jaksa Agung mengeluarkan Surat Edaran Jaksa Agung Nomor SE004/J.A/11/1993 tentang Pembuatan Surat Dakwaan. Surat Edaran tersebut ditujukan agar dapat keseragaman para Penuntut Umum dalam membuat surat dakwaan. Dalam Surat Edaran ini, disebutkan tentang bentuk-bentuk surat dakwaan antara lain:

a. Dakwaan Tunggal

Dalam surat dakwaan ini hanya satu Tindak Pidana saja yang didakwakan, karena tidak terdapat kemungkinan untuk mengajukan alternative atau dakwaan pengganti lainnya;

b. Dakwaan Alternatif

Dalam surat dakwaan ini terdapat beberapa dakwaan yang disusun secara berlapis, lapisan yang satu merupakan alternatif mengecualikan dakwaan pada lapisan lainnya. Bentuk dakwaan ini digunakan bila belum didapat kepastian tentang Tindak Pidana mana yang paling tepat dapat dibuktikan. Dalam dakwaan alternatif, meskipun dakwaan terdiri dari beberapa lapisan, hanya satu dakwaan saja yang dibuktikan tanpa harus memperhatikan urutannya dan jika salah satu telah terbukti maka dakwaan pada lapisan lainnya tidak perlu dibuktikan lagi. Dalam bentuk Surat Dakwaan ini, antara lapisan satu dengan yang lainnya menggunakan kata sambung Atau.

c. Dakwaan Subsidair

Sama halnya dengan dakwaan alternatif, dakwaan subsidair juga terdiri dari beberapa lapisan dakwaan yang disusun secara berlapis dengan maksud lapisan yang satu berfungsi sebagai pengganti lapisan sebelumnya. Sistematik lapisan disusun secara berurut dimulai dari Tindak Pidana yang diancam dengna pidana tertinggi sampai dengan Tindak Pidana yang diancam dengan pidana terendah.

d. Dakwaan Kumulatif

Dalam Surat Dakwaan ini, didakwakan beberapa Tindak Pidana sekaligus, ke semua dakwaan harus dibuktikan satu demi satu. Dakwaan yang tidak terbukti harus dinyatakan secara tegas dan dituntut pembebasan dari dakwaan

\footnotetext{
${ }^{12}$ https://blog.sribu.com/id/pengertian-media-sosial/
} 


\section{PATIK : JURNAL HUKUM Vol : 09 No. 1, April 2020, Hal 60 - 69}

tersebut. Dakwaan ini dipergunakan dalam hal Terdakwa melakukan beberapa Tindak Pidana yang masing-masing merupakan Tindak Pidana yang berdiri sendiri.

e. Dakwaan Kombinasi

Dakwaan Kombinasi adalah surat dakwaan yang merupakan kombinasi dari dakwaan yang berbentuk alternatif dengan dakwaan subsidair/antara dakwaan kumulatif dengan dakwaan subsidair/antara dakwaan kumulatif dengan dakwaan alternatif, dan sebagainya. Dakwaan ini harus diperhatikan secara teliti mengenai bentuk-bentuk dari kumulasinya, dan jangan sampai upaya untuk mencegah terdakwa lepas dari dakwaan justru memperluas kemungkinan terdakwa untuk lepas dari dakwaan. Timbulnya bentuk ini seiring dengan perkembangan di bidang kriminalitas yang semakin variatif baik dalam bentuk/jenisnya maupun modus operasi yang digunakan.

Berdasarkan surat dakwaan yang diberikan penuntut umum yang didakwakan terhadap terdakwa, dalam kronologis yang disebutkan pada Putusan Nomor 196/Pid.Sus/2019/PN Bks. Sangat jelas disebutkan bahwa terdakwa secara sadar dan sengaja menyebarkan postingan ke facebook yang berisi penghinaan dan pencemaran nama baik yang dapat menjatuhkan wibawa Kepala Negara. Terdakwa memposting ke akun facebook nya yang berisi muatan pencemaran nama baik dan menyebarkan berita bohong atau hoax yang mengarah kepada Kepala Negara karena merasa kesal dengan kepemimpinan Presiden yang dikira terdakwa tidak memperdulikan umat muslim di Indonesia. Terdakwa terus melakukan hal tersebut tanpa merasa bersalah karena berlindung didalam kedok ormas-ormas keagamaan.

Penulis sepakat dengan dakwaan yang diberikan oleh penuntut umum karena dakwaan yang diberikan terdiri dari dakwaan alternatif yaitu dakwaan yang berisikan tentang perbuatan yang dilakukan oleh terdakwa yang menyebarkan berita bohong atau hoax dengan tujuan menghina dan mencemarkan nama baik Presiden sesuai dengan dakwaan kesatu pasal 45 ayat (3) jo. Pasal 27 ayat (3) Undang-Undang nomor 19 tahun 2016 tentang Perubahan atas Undang-Undang nomor 11 tahun 2008 UU ITE atau pasal 207 KUHP. Penuntut Umum menggunakan ini karena tindak pidana yang satu dengan lainnya saling berhubungan. Dakwaan ini harus diperhatikan secara teliti mengenai bentukbentuk dakwaan nya, jangan sampai dakwaan yang diberikan malah meringankan terdakwa.

Adapun yang menjadi tuntuntan penuntut umum menuntut terdakwa Ashyadu Amrin adalah dengan pasal 45 ayat (3) jo. Pasal 27 ayat (3) Undang-Undang Nomor 19 tahun 2016 tentang Perubahan atas Undang-Undang nomor 11 tahun 2008 UU ITE dan Pasal 207 KUHP. Dalam tuntutan yang diajukan oleh Jaksa Penuntut Umum, terdakwa dituntut pidana penjara selama 4 tahun. Berdasarkan perbuatan yang dilakukan oleh terdakwa mengakibatkan dampak yang besar terhadap program pemerintah dalam mengurangi dan mencegah peredaran berita bohong atau hoax di Indonesia dan berdasarkan fakta-fakta hukum yang ditemui dalam persidangan maka saya setuju dengan tuntutan yang dituntut oleh penuntut umum karena menurut penulis, tuntutan yang diberikan oleh penuntut umum sangat tepat karena dalam tuntutan oleh penuntut umum, terdakwa memenuhi unsur pasal 45 ayat (3) jo. Pasal 27 ayat (3) Undang-Undang Nomor 19 tahun 2016 tentang perubahan Perubahan atas Undang-Undang nomor 11 tahun 2008 UU ITE dan Pasal 207 KUHP. Sehingga pidana pokok yang dijatuhkan kepada terdakwa sudah cukup untuk memberikan efek jera terhadap terdakwa agar tidak melakukannya lagi.

Adapun yang menjadi dasar pertimbangan hakim dalam menjatuhkan hukuman kepada terdakwa didasarkan pada fakta-fakta hukum yang ditemukan dalam proses 


\section{PATIK : JURNAL HUKUM Vol : 09 No. 1, April 2020, Hal 60 - 69}

penyidikan sampai dengan proses persidangan yang di dalamnya terdapat dasar pertimbangan hakim bersifat yuridis dan non yuridis. Yang menjadi dasar pertimbangan hakim dalam menjatuhkan putusan bersifat yuridis yaitu:

a. Adanya dakwaan penuntut umum yang merupakan dasar dari jalannya sautu pemeriksaan dalam proses persidangan untuk mengetahui tindak pidana yang dilakukan, yaitu dalam analisis penulis maka tindak pidana yang terjadi adalah tindak pidana informasi dan transaksi elektronik.

b. Keterangan Terdakwa oleh Ashyadu Amrin.

Terdakwa mengakui dengan sengaja dan tanpa paksaan telah melakukan suatu perbuatan tidak pidana sesuai dengan dakwaan penuntut umum yang merupakan tindak pidana informasi dan transaksi elektronik. Yaitu dengan cara menyebarkan berita bohong atau hoax berisi pencemaran nama baik yang ditujukan kepada Kepala Negara agar martabatnya jatuh di hadapan masyarakat.

c. Keterangan Saksi

Dalam hal keterangan saksi, dalam Putusan Nomor 194/Pid.Sus/2019/PN Bks, saksi didatangkan oleh penuntut umum yaitu saksi Wisnu Widiatmoko, S.Kom, Alan Umar Mawardi, Ericson Gaja yang juga bekerja sebagai anggota kepolisian di Satgas Patroli Siber pada Direktorat Tindak Pidana Siber Mabes Polri telah bersumpah terlebih dahulu sebelum memberikan informasi dimuka persidangan. Selain itu juga Jaksa Penuntut Umum mendatangkan saksi yang berhubungan dengan tindak pidana tersebut yakni saksi Mohammad Umar Muslim, S.S., M.A.,Ph.D.

d. Barang Bukti

Adapun yang menjadi barang bukti dalam persidangan yang diajukan oleh penuntut umum antara lain:

1) 3 (tiga) lembar screen shoot/ Print out hasil postingan dari Akun Facebook Asyhadu Amrin yang berkonten penghinaan

2) 1(satu) buah akun facebook dengan nama ASHYADU AMRIN ID $100006318365980 \quad$ dengan url https://www.facebook.com/profile.php?id=100006318365980, yang di export ke dalam bentuk CD, beserta 1 (satu) bundle print outnya.

3) 1(satu) buah akun email dengan nama ASHYADU AMRIN (ashyaduamrin212@gmail.com) dengan url https://myaccount.google/?utmsource=OGM\&utmmedium=act\&pli=1, yang di export ke dalam bentuk CD, beserta 1(satu) bundle print outnya.

4) 1 (satu) buah akun email dengan nama MILITAN KEADILAN (satriadirgantara86@gmail.com) dengan url https://myaccount.google.com/?utmsource=OG\&utm medium=act, yang diexport ke dalam bentuk CD, beserta 1 (satu) bundle print out nya.

5) 1(satu) pucuk Airsoftgun tipe baby AK dengan Nomor YQ 10 N 07568.

6) 1 (satu) unit Handphone Xiomi Redmi3C.

7) 1 (satu) buah SIM Card Telkomsel dengan nomor 0812111066684.

8) 1 (satu) buah Banner bertuliskan Posko Peduli Kemanusiaan "MILITAN KEADILAN".

9) 1 (satu) buah Bendera Forum Umat Islam.

10) 1 (satu) buah Jaket MILITAN KEADILAN.

Sedangkan dasar pertimbangan hakim lainnya yang menjadi dasar pertimbangan Majelis Hakim dalam menjatuhkan hukuman yaitu dasar pertimbangan yang bersifat non 


\section{PATIK : JURNAL HUKUM Vol : 09 No. 1, April 2020, Hal 60 - 69}

yuridis berupa latar belakang terdakwa, keadaan jiwa terdakwa, dampak dari perbuatan terdakwa dan agama terdakwa. Selain pada itu, hakim juga mempertimbangkan unsurunsur tindak pidana yang diduga di lakukan oleh terdakwa Ashyadu Amrin, yaitu:

Unsur-unsur pada Pasal 45 ayat (3) Jo Pasal 27 ayat (3) Undang-Undang Nomor 19 tahun 2016 tentang Perubahan atas Undang-Undang Nomor 11 tahun 2008 tentang Informasi Transaksi Elektronik yaitu:

Ad. 1. Unsur Setiap Orang

Bahwa yang dimaksud dengan unsur setiap orang adalah pelaku/subjek hukum yang melakukan tindak pidana baik itu laki-laki atau perempuan yang merupakan pendukung hak dan kewajiban. Dalam unsur Setiap Orang ini adalah orang yang merupakan terdakwa Ashyadu Amrin dan merupakan subjek hukum yang dapat mempertanggungjawabkan perbuatannya. Oleh karena itu Majelis Hakim berpendapat bahwa unsur setiap orang telah terpenuhi.

Ad. 2. Unsur "Dengan Sengaja dan Tanpa Hak"

Dalam kasus ini sangat jelas Terdakwa Tanpa Hak menyebarkan berita bohong/hoax di halaman facebooknya yang bertujuan untuk mencemarkan nama baik Kepala Negara agar martabat nya jatuh dihadapan masyarakat. Dan juga Terdakwa memenuhi unsur Dengan Sengaja. Terdakwa menunggah atau memposting di facebooknya secara sengaja karena kesal melihat Kepala Negara tidak memperdulikan masyarakat khususnya umat Muslim.

Ad. 3. Unsur Mendistribusikan dan/atau mentransmisikan dan/atau membuat dapat diaksesnya Informasi Elektronik dan/atau Dokumen Elektronik yang memiliki muatan penghinaan dan/atau pencemaran nama baik.

Sangat jelas dalam kasus ini Terdakwa menyebarkan postingan di facebook dan memiliki teman sejumlah 1.091, maka semua teman facebook Terdakwa dapat melihat postingan terdakwa yang menyebarkan berita bohong/hoax dan berisi penghinaan atau pencemaran nama baik terhadap Kepala Negara. Karena dakwaan Jaksa Penuntut Umum yang relatif, apabila unsur pada dakwaan pertama sudah terpenuhi maka dakwaan kedua tidak perlu dipertimbangkan lagi. Setelah menganalisis kasus Putusan Nomor 196/Pid.Sus/2019/PN Bks, maka penulis mengambil kesimpulan mengenai pemidanaan terhadap pelaku tindak pidana adalah bahwa terdakwa Ashyadu Amrin telah terbukti secara sah dan meyakinkan bersalah melakukan tindak pidana "Dengan Sengaja dan Tanpa Hak menyebarkan berita bohong/hoax yang dapat menjatuhkan martabat Kepala Negara. Hal ini terbukti bahwa dalam persidangan Jaksa Penuntut Umum mengajukan dakwaaan alternatif yaitu dakwaan kesatu Pasal 45 ayat (3) Jo. Pasal 27 ayat (3) Undang-undang Nomor 19 tahun 2016 tentang Perubahan atas Undang-Undang Nomor 11 tahun 2008 tentang Informasi Transaksi Elektronik, yang unsur-unsurnya terdiri dari :

1. Unsur Setiap Orang

Setiap orang disini adalah laki-laki atau perempuan yang bisa menjadi objek hukum dalam melakukan suatu tindak pidana.

2. Dengan Sengaja dan Tanpa Hak

Terdakwa terbukti melakukan perbuatan pencemaran nama baik dan menyebarkan berita bohong atau hoax dengan sengaja dan secara sadar melakukan perbuatan tersebut. Terdakwa juga melakukan itu tanpa hak karena berita yang diberikan oleh terdakwa tidak benar adanya dan tanpa persetujuan dari korban yang juga sebagai Kepala Negara.

3. Unsur Mendistribusikan dan/atau mentransmisikan dan/atau membuat dapat diaksesnya Informasi Elektronik dan/atau Dokumen Elektronik yang memiliki muatan penghinaan dan/atau pencemaran nama baik.Atau 


\section{PATIK : JURNAL HUKUM Vol : 09 No. 1, April 2020, Hal 60 - 69}

dakwaan kedua pasal 207 KUHP yaitu barang siapa dengan sengaja dimuka umum dengan lisan atau tulisan menghina suatu penguasa atau badan umum yang ada di Indonesia, diancam dengan pidana penjara paling lama satu tahun enam bulan atau pidana denda paling banyak empat ribu lima ratus rupiah.

Dengan memperhatikan uraian unsur-unsur diatas, dengan demikian telah terbukti secara sah menurut hukum dan meyakinkan. Majelis hakim juga menjatuhkan pidana penjara selama 2 (dua) tahun 6 (enam) bulan kepada terdakwa. Penulis tidak sepakat dengan putusan hakim yang menjatuhkan pidana penjara selama 2 (dua) tahun 6 (enam) bulan kepada terdakwa, hakim tidak menyesuaikan hukuman dengan perbuatannya yang menyebarkan berita bohong yang berisi penghinaan dan pencemaran nama baik dan menjatuhkan martabat Kepala Negara. Seharusnya hakim menjatuhkan hukuman sesuai dengan tuntutan Jaksa Penuntut Umum, karena Kepala Negara adalah simbol tertinggi dalam suatu negara. Apabila terdakwa yang melakukan tindak pidana tersebut dihukum lebih berat maka orang lain tidak akan sesuka hati dan berani menyebarkan berita bohong atau hoax yang mengarah atau menyerang Kepala Negara agar martabatnya jatuh dihadapan masyarakat banyak.

\section{Kesimpulan Dan Saran}

Dalam perkara putusan Nomor 196/Pid.Sus/2019/PN Bks, Jaksa mendakwa terdakwa dengan dakwaan kesatu yakni Pasal 45 Ayat (3) jo. Pasal 27 Ayat (3) UndangUndang Nomor 19 Tahun 2016 tentang Perubahan atas Undang-Undang Nomor 11 Tahun 2008 tentang Informasi dan Transaksi Elektronik dan unsur-unsur telah terpenuhi. Dan dakwaan kedua Pasal 207 KUHP dan dakwaan tersebut telah terpenuhi. Maka Jaksa menuntut terdakwa dengan dua tuntutan dengan hukuman selama 4 (empat) tahun penjara. Sebelum menjatuhkan putusan Majelis Hakim terlebih dahulu melihat aspek-aspek lain seperti alasan pemaaf dan penghapusan pidana. Tetapi Majelis Hakim tidak menemukan hal-hal yang dapat menghapuskan pertanggungjawaban pidana sebagai alasan pemaaf maupun penghapusan pidana, dan Terdakwa mengakui secara sadar dan tanpa paksaan melakukan tindak pidana tersebut. Maka Terdakwa harus mempertanggungjawabkan perbuatan dan karena Terdakwa mampu bertanggungjawab maka dinyatakan bersalah dan dijatuhi pidana penjara selama 2 (dua) tahun 6 (enam) bulan. Perlu adanya penindakan tegas terhadap pelaku yang menyebarkan berita bohong atau hoax tentang Presiden. Apabila aparat penegak hukum tidak tegas dalam menangani kasus seperti ini, maka makin banyak masyarakat yang semena-mena menyebarkan berita hoax dan mencemarkan nama baik Presiden.

\section{DAFTAR PUSTAKA}

\section{Buku}

Ali. Mahrus. Asas-Asas Hukum Pidana Korporasi. Jakarta: Grafindo Persada, 2011.

Ali. Mahrus. Dasar-Dasar Hukum Pidana. Jakarta: Sinar Grafika, 2011.

Armia. Tgk Siddiq. Perkembangan Pemikiran Dalam Ilmu Hukum. Jakarta: Pradnya Paramita, 2003.

Chazawi. Adami. Tindak Pidana Informasi \& Transaksi Elektronik. Malang: Media Nusa Creative, 2015.

Chazawi. Adami. Hukum Pidana Positif Penghinaan. Malang: Media Nusa Creative, 2016. 


\section{PATIK : JURNAL HUKUM Vol : 09 No. 1, April 2020, Hal 60 - 69}

Gunadi. Ismu. Hukum Pidana. Jakarta: Kencana, 2014.

Hamzah. Andi. Delik-Delik Tertentu di dalam KUHP. Jakarta: Sinar Grafika, 2010.

Hiareij. Eddy O.S. Prinsip-Prinsip Hukum Pidana. Yogyakarta: Cahaya Atma Pustaka, 2015.

Ishaq. Hukum Pidana. Jakarta: Rajagrafindo Persada, 2020.

Lamintang. Dasar-Dasar Hukum Pidana di Indonesia. Jakarta: Sinar Grafika, 1997.

Marpaung. Leden. Tindak Pidana Terhadap Kehormatan. Jakarta: Sinar Grafika, 2010.

Marzuki. Peter Mahmud. Penelitian Hukum. Jakarta: Pranata Media Grup, 2015.

Prasetyo. Teguh. Hukum Pidana. Jakarta: Rajagrafindo Persada, 2010.

Renggong. Ruslan. Hukum Pidana Khusus Memahami Delik-Delik Diluar KUHP. Jakarta: Prenamedia Grup, 2016.

Rianto. Agus. Tindak Pidana Pertanggungjawaban Pidana. Surabaya: Kencana, 2016.

Siregar. Gomgom. Suatu Analisis Mengenai Tindak Pidana Pencemaran Nama Baik Melalui Media Elektronik. Bandung: Refika Aditama, 2020.

Saleh. Roeslan. Perbuatan Pidana Dan Pertanggungjawaban Pidana. Jakarta: Aksara Baru, 2012.

Wahid. Abdul. Kejahatan Mayantara. Bandung: Refika Aditama, 2010.

Undang-Undang Nomor 19 tahun 2016 tentang Perubahan Atas Undang-Undang Nomor 11 tahun 2008 tentang Informasi dan Transaksi Elektronik 